\title{
Introduction to Special Issue on Innovations in Research Methods in Accounting and Governance
}

\author{
Niamh M. Brennan ${ }^{1}$ (D), Patricia Martyn ${ }^{2}$ \\ ${ }^{1}$ University College Dublin, ${ }^{2}$ National University of Ireland, Galway \\ Keywords: quantitative research, qualitative research, methodology, research methods \\ https://doi.org/10.52399/001c.22169
}

Accounting, Finance \& Governance Review

Vol. 27, 2021

This paper introduces the five papers in this special issue on innovations in research methods in accounting and governance. We also add commentary on areas for which we did not receive papers, which we believe are ripe for future innovative research methods.

\section{Introduction}

Accounting and governance research has grown in size and importance, developing into global, interdisciplinary research fields. Academics are faced with relentless pressures for higher-quality research that contributes to their discipline. The search for innovative methods to advance accounting and governance theory has been continuous with significant improvements in recent years. The key question in this special issue is how to study accounting and governance issues better, to provide useful insights for both theory and practice. Scholars have relied on various methodological approaches to address these issues, including case studies, surveys, archival analysis, ethnography and experiments. How research is conducted is subject to scrutiny. It is becoming increasingly important for researchers to demonstrate critical and reflective approaches to their methods of enquiry. Today, the field is undergoing rapid transformation in methodological possibilities. This presents researchers with new opportunities to better capture phenomena of interest in their investigations and new challenges on how to conduct their studies and to understand the implications associated with their research choices. Given this context, the purpose of this special issue is to give impetus to advances in qualitative and quantitative research methodologies in the fields of accounting and governance.

In this special issue, we sought papers that address new or non-mainstream methodological approaches, focusing on the description of methodologies or the process of doing research and the lessons learned rather than on outcomes (if any). We sought contributions addressing both developments in new research methodologies and contributions addressing pragmatic improvements in established research methods. We also invited critical reflections about important methodological issues, including ethical and social impacts, the harnessing of technology to engage with the field, novel types of researchers' engagement with empirical reality, and different relationships between researchers and subjects for research. We sought to (a) codify existing difficulties in how methods are applied, (b) develop an understanding on how 
Table 1. Summary of the Papers in this Special Issue

\begin{tabular}{|c|c|c|c|c|}
\hline Authors & Focus & Methodology & Method & Domain \\
\hline $\begin{array}{l}\text { Cullen \& } \\
\text { Brennan } \\
\text { (2021) }\end{array}$ & Methodology & Grounded theory & Interviews & Accounting \\
\hline $\begin{array}{l}\text { Conaty } \\
(2021)\end{array}$ & Methodology & Abductive reasoning & Case study & $\begin{array}{l}\text { Management } \\
\text { accounting }\end{array}$ \\
\hline $\begin{array}{l}\text { Farrell \& } \\
\text { Sweeney } \\
\text { (2021) }\end{array}$ & Data collection & $\begin{array}{l}\text { Sourcing survey and } \\
\text { experimental data }\end{array}$ & $\begin{array}{l}\text { Amazon's } \\
\text { Mechanical Turk } \\
\text { "MTurk" }\end{array}$ & $\begin{array}{l}\text { Review of adoption of } \\
\text { MTurk in accounting }\end{array}$ \\
\hline $\begin{array}{l}\text { Mattimoe et } \\
\text { al. (2021) }\end{array}$ & $\begin{array}{l}\text { Selection from two data } \\
\text { analytical approaches }\end{array}$ & $\begin{array}{l}\text { Computer-aided versus } \\
\text { manual content analysis }\end{array}$ & Interviews & $\begin{array}{l}\text { Decision making; } \\
\text { professional } \\
\text { competence }\end{array}$ \\
\hline $\begin{array}{l}\text { Martyn } \\
\text { (2021) }\end{array}$ & $\begin{array}{l}\text { Specific analytical } \\
\text { method }\end{array}$ & Data reduction techniques & Interviews & $\begin{array}{l}\text { Management control } \\
\text { systems }\end{array}$ \\
\hline
\end{tabular}

to resolve current dilemmas through new methodological approaches, (c) lay a foundation for increased emphasis on methodological quality in future studies, and (d) consider the implications of methodological quality on developments in accounting and governance. Our objective was to assemble research evidence, cutting-edge ideas and potential solutions to promote better, more innovative research methods for high-quality research.

In Table 1, we summarise the five papers included in the special issue (in the order of their inclusion). They span a range of methodologies, methods and domains. Cullen \& Brennan (2021) focus on grounded theory methodology. Their paper draws together prior literature to summarise the original grounded theory core tenets. They build on this by considering both recent thinking and its application in accounting research. By identifying grounded theory quality criteria, the paper assists researchers to better understand and apply the methodology.

Conaty (2021) reminds us that validity and generalisability of findings in interpretative qualitative research is a central concern. Focusing on abduction as a methodological approach, Conaty documents the careful attention required to support his management accounting case study's validity and generalisability. The paper summarises his experiences of abduction and establishes good practices that serve as a useful guide for abductive researchers.

Farrell \& Sweeney (2021) review Amazon's Mechanical Turk (MTurk) as a data collection tool in accounting studies. They report a growing adoption of MTurk in experimental studies. They suggest that the tool is suitable for survey research and will gain traction for pre-testing and pilot-testing survey instruments. Their paper draws our attention to the opportunities offered by MTurk for conducting efficient replication studies.

Qualitative research data analysis is the subject of Mattimoe et al. (2021). Their paper examines how two $\mathrm{PhD}$ researchers analysed their qualitative data using two different approaches. They highlight the factors influencing the choice of approach and the challenges they encountered. The paper provides helpful insights for early-stage $\mathrm{PhD}$ students making data analysis choices. Martyn (2021) also focusses on analysing qualitative data and highlights how 
Table 2. Example Papers Mobilising Under-used Research Methods

\begin{tabular}{|c|c|c|c|}
\hline $\begin{array}{l}\text { Methodology/ } \\
\text { method }\end{array}$ & Financial accounting & Management accounting & Governance \\
\hline $\begin{array}{l}\text { Autoethnography/ } \\
\text { Ethnography }\end{array}$ & $\begin{array}{l}\text { Atkins et al. (2015); } \\
\text { Graaf \& Johed (2020); } \\
\text { Zicari \& Perera- } \\
\text { Aldama (2020); Zou } \\
\text { (2021) }\end{array}$ & $\begin{array}{l}\text { Amslem \& Gendron (2019); Ligonie } \\
\text { (2021); Agostino \& Sidorova } \\
\text { (2017); Bialecki et al. (2017); } \\
\text { Begkos \& Antonopoulou (2020) }\end{array}$ & $\begin{array}{l}\text { Parker (2007a, 2007b); Samra- } \\
\text { Fredericks (2000a, 2000b) }\end{array}$ \\
\hline Video recording & & Johansson \& Baldvinsdottir (2003) & $\begin{array}{l}\text { Bezemer et al. (2014, 2018); Pugliese } \\
\text { et al. (2015); Nicholson et al. (2017); } \\
\text { Veltrop et al. (2021); Pernelet \& } \\
\text { Brennan (2021a, 2021b) }\end{array}$ \\
\hline Focus groups & Gammie et al. (2017) & Dossi \& Patelli (2008) & \\
\hline Interpretive & Kenno et al. (2017) & Vaivio (2006) & \\
\hline $\begin{array}{l}\text { Social } \\
\text { constructionist }\end{array}$ & Rutherford (2003) & $\begin{array}{l}\text { Malmi et al. (2004); Modell (2012); } \\
\text { Ashraf \& Uddin (2015); Lye et al. } \\
\text { (2020) }\end{array}$ & \\
\hline
\end{tabular}

the analysis of large volumes of qualitative data at $\mathrm{PhD}$ stage can be challenging. To mitigate this challenge, she uses quantitative analytical protocols. Her paper details the steps involved, including a reflection on the merits and difficulties she encountered.

\section{Prior Research Adopting Innovative Research Methods}

Table 2 suggests further reading on innovative financial accounting/ reporting, management accounting and corporate governance research methods.

\subsection{Financial Accounting and Corporate Reporting}

Rutherford (2010) urges a return to classical approaches to financial accounting research, which have been replaced by neo-empiricism which largely replicate US research thrust. Arnold (2009) observes that too much financial accounting research is limited and ultimately shaped by quantitative databases' availability. This quantitative stream of the literature is also a crowded field. Alternative methodologies and methods provide researchers with opportunities to find a niche from which to contribute original ideas to prior research. In discussing case study research, Cooper \& Morgan (2008) recommend selecting extreme outliers. Fogarty (2017) recommends action research for the study of financial accounting. Action research comes from sociology, political science and management. Action research is where a researcher and organisation collaborate, with the objective of achieving organisation change. Fogarty (2017) provides examples of circumstances where such an approach would suit financial accounting research. We know little about how financial reports are assembled inside organisations. Grounded theory provides an opportunity to research such processes. Gibbins et al. (1990) is an early example of such research.

Atkins et al. (2015) consider integrated reporting through the lens of autoethnography and other original methodological approaches, including analysis of dialogue, a utopian metaphor of an ecologically sound society and oral disclosures. Graaf \& Johed (2020) use an ethnographically inspired 
approach to study how equity sales' brokers use accounting to make investment decisions. They examine how brokers understand accounting through their diverse activities. In a highly original approach, Zicari \& PereraAldama (2020) narrate the inside story of how a Big Four partner created a social reporting model for use in South American countries. The paper is written in a highly personalised style, using the first person to describe the process of writing the auto-ethnographic story. Zou (2021) uses autoethnography to describe conducting fieldwork in China. She uses the first person to write her fieldwork diaries and vignettes, focussing on her experiences and how she coped with managing the fieldwork.

Gammie et al. (2017) review a novel approach to data collection, in the form of focus groups, which they find has been rarely used in prior accounting research. Kenno et al. (2017) provide a primer for conducting financial reporting field research using interview methods, although their "positivist" approach may not find favour with all interpretive researchers. Visual approaches lend themselves to financial reporting research, as illustrated by Courtis (2004) and Davison (2004, 2007, 2010, 2011). Some accounting researchers adopt a social constructionist approach, following Hines' (1988) seminal paper, "in communicating reality we construct reality", of which Rutherford (2003) is an exemplar.

\subsection{Management Accounting}

Amslem \& Gendron (2019) describe an ethnographic approach, supplemented by participant observation and interviews, to study how social workers use quantitative accounting data. Ligonie (2021) describes her ethnographic approach in detail, including revealing that she spent 70 days shadowing a sustainability team to study its use of sustainability control tools. Ethnographic research techniques have adapted to take advantage of the opportunities offered by the internet and digital platforms (Kozinets, 2010). Netnography explores social interactions across digital platforms and social media (Begkos \& Antonopoulou, 2020). This technique has been mobilised in several management accounting studies. Agostino \& Sidorova (2017) investigate how social media interactions impact on the distance between a telecommunications company and its customers. To complement interview data, they analyse communications on the corporate website and social media platforms, including number of likes and tweets. Bialecki et al. (2017) examine how management accounting tools are embedded within the Internet Movie Database (IMDb) and shape social outcomes. They use online film reviews posted to IMDb, contending that these posts represent important judgement devices for constructing individual preferences. In their study of evaluative practices and performance indicators, Begkos \& Antonopoulou (2020) use netnographic methods to capture interactions within a Greek Instagram community.

In executing their longitudinal case study, Johansson \& Baldvinsdottir (2003) adopt interviews, video recordings, field observations and sociograms to collect their data. Sociograms capture in visual terms their construct of interest, 
trust, which they illustrate in their paper. Dossi \& Patelli (2008) supplement survey-based results with focus groups, allowing them to identify issues relating to the use of performance measurement in the relationships between headquarters and subsidiaries.

Lukka \& Modell (2010) review interpretive research in management accounting research, of which Vaivio (2006) is an exemplar. They commend his detailed and rich descriptions, which is typical of this type of research. Elharidy et al. (2008) review the use of grounded theory as an interpretive approach to management accounting research. In their study of the cost of poor quality management, Malmi et al. (2004) commence with interviews but move to cross-functional workshops as a superior means of data collection. Jönsson \& Lukka (2006) describe Malmi et al.'s approach as interventionist. Bromwich \& Scapens (2016) recommend interventionalist research to provide knowledge of current management accounting practices and increase research impact. Modell (2012) studies strategy discourses, constructing case narratives in respect of his case company. Ashraf \& Uddin (2015) conduct an intensive case study in a politically unstable context to study the significance of power groups to management accounting control changes. They acknowledge the difficulty of access to such case material, which in their case was via a former student. Lye et al. (2020) exemplify social constructivist research in management accounting. They study how employees socially construct reality, constructing knowledge from their everyday use of organisational processes, namely the performance measurement system. Bromwich \& Scapens (2016) encourage management accounting scholars to use a variety of research methods to help strengthen the diversity in management accounting research.

\subsection{Governance}

Cullen \& Brennan (2017) apply grounded theory to study mutual fund boards, an extreme board type. They use grounded theory methodology to develop theory on investment fund boards' role from the ground up. They conduct 25 interviews with non-executive directors (16) and fund promoter executive directors (9). Their theoretical insights extend understanding of the differentiation of control, monitoring and oversight functions of boards of directors. Mutual fund boards can only exercise oversight due to the power imbalance between those boards and fund promoters. Interview-based research on boards is common. However, researchers can only obtain insights on boards of directors at a distance, through what interviewees tell them.

Boards of directors are difficult to research, given access challenges to the "black box of the boardroom" (Watson et al., 2021). Watson et al. (2021) review the sparse research penetrating the boardroom using observational methods. They refer to this research as "processual" in that it focuses on procedures relating to governance. Parker (2007a, 2007b) opens the black box of the boardroom through his autoethnographic participant observation study. Samra-Fredericks (2000a, 2000b) ethnographic study is a game-changer in that she uses audio and video recordings to study directors' and managers' talkbased interpersonal routines. Bezemer et al. (2014) videotape six board 
meetings and use the data collected to analyse various aspects of board processes, including patterns of director interactions (Pugliese et al., 2015), habitual accountability routines (Nicholson et al., 2017), the influence of board chairs (Bezemer et al., 2018). Veltrop et al. (2021) videotape seven board meetings of five Australian companies to analyse CEO-board cognitive conflict and chair leadership. Adopting a similar method, Pernelet \& Brennan (2021a, 2021b) videotape nine board meetings to study non-executive directors' and managers' question-and-answer interactions. The three boards they study meet in public in front of stakeholders and in private, allowing director behaviours in the two settings to be observed and analysed.

\section{Conclusion}

It is difficult to find opportunities to make an original contribution to the prior literature. Novel research methods and methodologies are one way to identify and address new research questions and to fill literature gaps. This special introduction presents five papers using under-used accounting research methods, supplemented by a review of papers in the prior literature using further under-used approaches.

\section{Acknowledgements}

The authors are grateful to Ray Donnelly, Philip O’Regan and Breda Sweeney for their enthusiastic support of this special issue. We extend our thanks to colleagues for their support of the special issue through submitting their papers for consideration. Finally, we thank the reviewers for their expertise and diligent work. 


\section{References}

Agostino, D., \& Sidorova, Y. (2017). How social media reshapes action on distant customers: Some empirical evidence. Accounting, Auditing $\Xi^{0}$ Accountability Journal, 30(4), 777-794. https://doi.org/10.1108/aaaj-07-2015-2136

Amslem, T., \& Gendron, Y. (2019). From emotionality to the cultivation of employability: An ethnography of change in social work expertise following the spread of quantification in a social enterprise. Management Accounting Research, 42, 39-55. https://doi.org/10.1016/ j.mar.2018.06.001

Arnold, P. J. (2009). Global financial crisis: The challenge to accounting research. Accounting, Organizations and Society, 34(6-7), 803-809. https://doi.org/10.1016/j.aos.2009.04.004

Ashraf, J., \& Uddin, S. (2015). Military, 'managers' and hegemonies of management accounting controls: A critical realist interpretation. Management Accounting Research, 29, 13-26. https://doi.org/10.1016/j.mar.2015.07.002

Atkins, J., Atkins, B. C., Thomson, I., \& Maroun, W. (2015). “Good” news from nowhere: Imagining utopian sustainable accounting. Accounting, Auditing छ Accountability Journal, 28(5), 651-670.

Begkos, C., \& Antonopoulou, K. (2020). Measuring the unknown: Evaluative practices and performance indicators for digital platforms. Accounting, Auditing $\Xi^{9}$ Accountability Journal, 33(3), 588-619. https://doi.org/10.1108/aaaj-04-2019-3977

Bezemer, P.-J., Nicholson, G., \& Pugliese, A. (2014). Inside the boardroom: Exploring board member interactions. Qualitative Research in Accounting E' Management, 11(3), 238-259. https://doi.org/ 10.1108/qram-02-2013-0005

Bezemer, P.-J., Nicholson, G., \& Pugliese, A. (2018). The influence of board chairs on director engagement: A case-based exploration of boardroom decision-making. Corporate Governance: An International Review, 26(3), 219-234. https://doi.org/10.1111/corg.12234

Bialecki, M., O'Leary, S., \& Smith, D. (2017). Judgement devices and the evaluation of singularities: The use of performance ratings and narrative information to guide film viewer choice. Management Accounting Research, 35, 56-65. https://doi.org/10.1016/j.mar.2016.01.005

Bromwich, M., \& Scapens, R. W. (2016). Management accounting research: 25 years on. Management Accounting Research, 31, 1-9. https://doi.org/10.1016/j.mar.2016.03.002

Conaty, F. (2021). Abduction as a methodological approach to case study research in management accounting - an illustrative case. Accounting, Finance $\sigma^{\circ}$ Governance Review, this issue.

Cooper, D. J., \& Morgan, W. (2008). Case study research in accounting. Accounting Horizons, 22(2), 159-178. https://doi.org/10.2308/acch.2008.22.2.159

Courtis, J. K. (2004). Colour as visual rhetoric in financial reporting. Accounting Forum, 28(3), 265-281. https://doi.org/10.1016/j.accfor.2004.07.003

Cullen, M. M., \& Brennan, N. M. (2017). Differentiating control, monitoring and oversight: Influence of power relations on boards of directors - Insights from investment fund boards. Accounting, Auditing $6^{\circ}$ Accountability Journal, 30(8), 1867-1894. https://doi.org/10.1108/ aaaj-12-2015-2345

Cullen, M. M., \& Brennan, N. M. (2021). Grounded theory: Description, divergences and application. Accounting, Finance E Governance Review, this issue.

Davison, J. (2004). Sacred vestiges in financial reporting: Mythical readings guided by Mircea Eliade. Accounting, Auditing E' Accountability Journal, 17(3), 476-497.

Davison, J. (2007). Photographs and accountability: Cracking the codes of an NGO. Accounting, Auditing $E^{\circ}$ Accountability Journal, 20(1), 133-158. https://doi.org/10.1108/09513570710731236 
Davison, J. (2010). [In]visible [in]tangibles: Visual portraits of the business elite. Accounting, Organizations and Society, 35(2), 165-183.

Davison, J. (2011). Barthesian perspectives on accounting communication and visual images of accountancy. Accounting, Auditing E Accountability Journal, 24(2), 250-283.

Dossi, A., \& Patelli, L. (2008). The decision-influencing use of performance measurement systems in relationships between headquarters and subsidiaries. Management Accounting Research, 19(2), 126-148. https://doi.org/10.1016/j.mar.2007.11.001

Elharidy, A. M., Nicholson, B., \& Scapens, R. W. (2008). Using grounded theory in interpretive management accounting research. Qualitative Research in Accounting $\sigma^{\circ}$ Management, 5(2), 139-155. https://doi.org/10.1108/11766090810888935

Farrell, M., \& Sweeney, B. (2021). Amazon's MTurk: A currently underutilised resource for survey researchers? Accounting, Finance E Governance Review, this issue.

Fogarty, T. J. (2017). Action research in accounting. In Z. Hoque, L. D. Parker, M. A. Covaleski, \& K. Haynes (Eds.), The Routledge Companion to Qualitative Accounting Research (pp. 231-249). Taylor $\&$ Francis.

Gammie, E., Hamilton, S., \& Gilchrist, V. (2017). Focus group discussions. In Z. Hoque, L. D. Parker, M. A. Covaleski, \& K. Haynes (Eds.), The Routledge Companion to Qualitative Accounting Research (pp. 372-386). Taylor \& Francis.

Gibbins, M., Richardson, A., \& Waterhouse, J. (1990). The management of corporate financial disclosure: Opportunism, ritualism, policies, and processes. Journal of Accounting Research, 28(1), 121-143. https://doi.org/10.2307/2491219

Graaf, J., \& Johed, G. (2020). Reverse brokering” and the consumption of accounting: A broker desk ethnography of an investment case. Accounting, Organizations and Society, 85, 101154.

Hines, R. D. (1988). Financial accounting: In communicating reality, we construct reality. Accounting, Organizations and Society, 13(3), 251-261. https://doi.org/10.1016/0361-3682(88)90003-7

Johansson, I.-L., \& Baldvinsdottir, G. (2003). Accounting for trust: Some empirical evidence. Management Accounting Research, 14(3), 219-234. https://doi.org/10.1016/ $\underline{\text { s1044-5005(03)00045-3 }}$

Jönsson, S., \& Lukka, K. (2006). There and back again: Doing interventionist research in management accounting. In C. S. Chapman, A. G. Hopwood, \& M. D. Shields (Eds.), Handbooks of Management Accounting Research (Vol. 1, pp. 373-397).

Kenno, S. A., McCracken, S. A., \& Salterio, S. E. (2017). Financial reporting interview-based research: A field research primer with an illustrative example. Behavioral Research in Accounting, 29(1), 77-102. https://doi.org/10.2308/bria-51648

Kozinets, R. V. (2010). Netnography: Doing Ethnographic Research Online. Sage Publications.

Ligonie, M. (2021). Sharing sustainability through sustainability control activities. A practice-based analysis. Management Accounting Research, 50, 100726.

Lukka, K., \& Modell, S. (2010). Validation in interpretive management accounting research. Accounting, Organizations and Society, 35(4), 462-477. https://doi.org/10.1016/j.aos.2009.10.004

Lye, J., Hoque, Z., \& Parker, L. (2020). How do employees learn from performance measures? Evidence from a local government entity. Accounting $E^{\circ}$ Finance. In press.

Malmi, T., Järvinen, P., \& Lillrank, P. (2004). A collaborative approach for managing project cost of poor quality. European Accounting Review, 13(2), 293-317. https://doi.org/10.1080/ $\underline{0963818042000204733}$

Martyn, P. (2021). Using quantitative analytical methods to support qualitative data analysis - lessons learnt during a $\mathrm{PhD}$ study. Accounting, Finance E Governance Review, this issue. 
Mattimoe, R., Hayden, M. T., Murphy, B., \& Ballantine, J. (2021). Approaches to analysis of qualitative research data: A reflection of the manual and technological approaches. Accounting, Finance E' Governance Review, this issue.

Modell, S. (2012). Strategy, political regulation and management control in the public sector: Institutional and critical perspectives. Management Accounting Research, 23(4), 278-295. https://doi.org/10.1016/j.mar.2012.05.001

Nicholson, G., Pugliese, A., \& Bezemer, P.-J. (2017). Habitual accountability routines in the boardroom: How boards balance control and collaboration. Accounting, Auditing E' Accountability Journal, 30(2), 222-246. https://doi.org/10.1108/aaaj-07-2015-2143

Parker, L. D. (2007a). Boardroom strategizing in professional associations: Processual and institutional perspectives. Journal of Management Studies, 44(8), 1454-1480.

Parker, L. D. (2007b). Internal governance in the nonprofit boardroom: A participant observer study. Corporate Governance: An International Review, 15(5), 923-934. https://doi.org/10.1111/ j.1467-8683.2007.00607.x

Pernelet, H. R., \& Brennan, N. M. (2021a). Challenge in the boardroom: Director-manager questionand-answer interactions at board meetings held in public and in private. University College Dublin.

Pernelet, H. R., \& Brennan, N. M. (2021b). Boards of directors performing governance: $A$ dramaturgical analysis. University College Dublin.

Pugliese, A., Nicholson, G., \& Bezemer, P.-J. (2015). An observational analysis of the impact of board dynamics and directors' participation on perceived board effectiveness. British Journal of Management, 26(1), 1-25. https://doi.org/10.1111/1467-8551.12074

Rutherford, B. A. (2003). The social construction of financial statement elements under Private

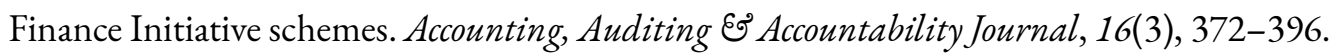
https://doi.org/10.1108/09513570310482336

Rutherford, B. A. (2010). The social scientific turn in UK financial accounting research: A philosophical and sociological analysis. Accounting and Business Research, 40(2), 149-171. https://doi.org/10.1080/00014788.2010.9663389

Samra-Fredericks, D. (2000a). Doing "Boards-in-Action" Research - an ethnographic approach for the capture and analysis of directors' and senior managers' interactive routines. Corporate Governance, 8(3), 244-257. https://doi.org/10.1111/1467-8683.00202

Samra-Fredericks, D. (2000b). An Analysis of the Behavioural Dynamics of Corporate Governance - a talk-based ethnography of a UK manufacturing "board-in-action." Corporate Governance, 8(4), 311-326. https://doi.org/10.1111/1467-8683.00210

Vaivio, J. (2006). The accounting of "The Meeting": Examining calculability within a "Fluid" local space. Accounting, Organizations and Society, 31(8), 735-762. https://doi.org/10.1016/ j.aos.2005.12.007

Veltrop, D. B., Bezemer, P.-J., Nicholson, G., \& Pugliese, A. (2021). Too unsafe to monitor? How board-CEO cognitive conflict and chair leadership shape outside director monitoring. Academy of Management Journal, 64(1), 207-234.

Watson, C., Husband, G., \& Ireland, A. (2021). Opening the 'black box': What does observational research reveal about processes and practices of governing? Journal of Management and Governance, 25(2), 189-221.

Zicari, A., \& Perera-Aldama, L. (2020). Building from scratch: An auto-ethnographic approach for the development of a social reporting model. Social and Environmental Accountability Journal, 40(2), 101-115. https://doi.org/10.1080/0969160x.2020.1765825 
Zou, Y. (2021). Experiencing and knowing in the field: An autoethnographic account of conducting audit fieldwork in China. Accounting, Auditing E'Accountability Journal, 34(3), 680-698. 